\title{
T regulatory cells during clinical manifestations of Asthma: A therapeutic standpoint
}

\author{
Mohammad $\operatorname{Khan}^{1}$ \\ ${ }^{1}$ king faisal hospital and research centre
}

May 5, 2020

\begin{abstract}
Asthma is a chronic inflammatory disease of the airways, which is considered to be mediated by the allergen-specific CD4+ $\mathrm{T}$ cells, Th2 cytokines, and allergen-specific IgE antibodies to play a key role in the initiation and perpetuation of chronic airway inflammation. The most common clinical manifestations of asthma are characterized by airway inflammation, airway obstruction, airway hyperresponsiveness, and airway microvascular remodeling. In addition to inflammatory cells, a tiny population of $\mathrm{T}$ regulatory cells (Tregs) control immune homeostasis, suppress allergic responses and participate in the resolution of inflammation-associated tissue injuries. Preclinical studies from animal models have demonstrated the huge therapeutic potential of Tregs in asthma conditions. Increasing evidence indicates that Tregs could be used to inhibit pathogenic asthma inflammation, and airway microvascular remodeling during the progression of asthma. This review addresses the relationship between locally accumulated Tregs and the development of asthmatic inflammation, and associated airway remodeling during the disease progression.
\end{abstract}

\section{Hosted file}

MS-CEI-draft 1.pdf available at https://authorea.com/users/295811/articles/424680-tregulatory-cells-during-clinical-manifestations-of-asthma-a-therapeutic-standpoint 